\title{
The Causes of the Subprime Mortgage Crisis and Its Enlightenment to China
}

\begin{abstract}
Haoran Ma
Pikes Peak Christian School, Colorado springs 80920, America

Corresponding author.Email:2479376491@qq.com

ABSTRACT

Based on the investigation of the four major economic crises in the history of the United States and the data at that time, this paper makes an in-depth analysis of the background of that economic crisis and its impact on economy and society. On this basis, the article makes a comparative analysis of the policies and measures taken by Alabama governments in response to the economic crisis and their effects. The analysis and logic of the article and chapter have important borrowing meanings for the Chinese government. This paper makes a comparative analysis of the policies adopted by the Alabama administration in the past economic crises and their effects, hoping to provide some references for the Chinese government to learn from the economic crises.
\end{abstract}

Keywords: macroeconomy, Economic crisis, Subprime crisis, Economic globalization

\section{INTRODUCTION}

Since the 1960 s of the 19 Century, with the development and widespread use of steam turbines as its symbol, Britain entered the first industrial revolution in human history. This revolution brought about two changes: From the mode of production, the factory system replaced the workshop-type worksite, and mechanical mass production replaced manual labor; As far as social relations are concerned, the industrial revolution has caused the yeoman class, which was originally attached to the backward mode of production, to disappear, and the bourgeoisie and the proletariat have gradually formed and become two classes of interests. On the one hand, the industrial revolution promoted the progress of science and technology. It promotes socialist production and led to the rapid expansion of productive capacity in capitalist countries. On the other hand, in order to increase capital accumulation, capitalists strengthen the stripping of the working class, and the growth rate of workers' labor capital is relatively slower. As a result, the contradiction between overproduction and effective demand is not enough to be stimulated. Eventually evolved into a capitalist economic crisis, so, in 1825 , the British broke out in the history of the world's first economic crisis [1]. This crisis has affected all trades and industries and affected the whole of Europe, but it has not caused any serious impact on other countries or regions in the world. It is not yet a worldwide economic crisis. In 1776, the United States established itself as the secondlargest manufacturing country in the world after Britain, following Britain's industrial revolution and the capitalist system. After 1865, US state-owned assets accumulated and increased rapidly. Total capital goods to increase every 10 years $45 \%$ a $60 \%$ rate up, the rate when the human mouth growth rate 2-3 times [2]. In 1880 , the industrial output value of the United States surpassed that of the United Kingdom and Germany. It became the world's largest industrial power, and the world's economic center was also transferred to the United States.

With the continuous promotion of large-scale mechanized production in the United States, the production capacity expanded rapidly, but the growth rate of workers and capital was still slow. Hence, the first economic crisis relief machine was launched in 1857 in the history of the United States [3-4]. After every 10 years left and the right time will burst an economic crisis. Each crisis not only made the whole society a huge damage to productivity, at the same time, also to the human economy and social development has brought a different degree of impact and even a devastating blow. 


\subsection{The Background and Influence of the US Subprime Mortgage Crisis}

Today, it has been 10 years since the financial crisis started in the United States in 2008 and swept the world, almost leading to the collapse of the world financial order. Until today, it still has a direct and indirect influence on our lives.It was also in this crisis that our country stepped forward and took great risks and responsibilities. It also started here and gradually moves towards the center of the world stage. However, taking on this huge risk and responsibility has left hidden dangers and risks for our current economic and financial system. The large-scale deleveraging and risk reduction policy being implemented in China is, to a certain extent, a continuation of the temporary measures taken in response to this major crisis in 2008. Systematic risks are not far from us.

The financial system is the center of resource allocation in modern society. Although it is classified as the tertiary industry, it is actually the authority and nervous system of a country or even the global economy. Information from all aspects is gathered here to become price signals, which also reflects the emotional fluctuations of market participants [5]. Therefore, some people say that the stock market is a barometer of the national economy. In the financial systems of developed countries and large developing countries, there is a wealth of the whole society and a large number of top talents. However, this system is not always as rational as the economics textbook says, because it can act crazily or even foolishly. It is no exaggeration to say that it is normal for the financial market to be irrational. This irrationality is mainly caused by the positive feedback characteristic of financial assets. The so-called positive feedback in the financial field refers to the rising asset price, which will attract capital and continue to push up its own price. Therefore, the initial period is just an accident, or a new investment target. The income of a few people in the early stage will attract a large amount of capital to gather and push up asset prices, while the increase of asset prices will attract new capital to enter and continue to push up the price. The accumulation of funds will increase the cost of obtaining funds for investors, which will eventually lead to the cost that no new funds can enter assets, and finally lead to the collapse of asset prices to the return of real value.

At that time, the Soviet Union disintegrated, and the American economy began to develop vigorously. It entered the golden age and enjoyed a good time until the new millennium. As a result, in 11th of September,2001, the plane hit the building, and the golden age was unexpectedly terminated by terrorist attacks. In 911 and the impact of the IT bubble burst, U.S. economy actually recession! When the new US President was George W. Bush, he launched the
Taliban's war on terror and the war on Iraq (2003) in a row with the outside world and introduced a package of economic stimulus plan at home. An important part of this plan is the "Home Ownership Plan". (in fact this plan has been since the Clinton era) [6]. In line with the leaders' economic stimulus plan, the fed dallied with interest rate cuts, and by 2003 , the federal funds rate fell to $1 \%$, the lowest in 45 years. In 2007 , the US economic crisis was mainly caused by the explosion of the subprime mogage crisis. The so-called sub-grade debt is the U.S. government's effort to encourage and help the lowincome group without a home to afford a home and create a credit market for those who would not otherwise be eligible to apply for a home loan. Finally, Congress even allocated funds to help first-time homebuyers pay the down payment. People who make these credit insufficient or have a poor loan record can also apply for a loan. The U.S. loan company does not use its own money to release bonds but sells these claims to banks. Banks do not use their own money to buy these bonds. Instead, through the financial innovation of investment banks, they devise a large number of financial derivatives, or package them into packages, which are then divided into "shares," and finally sold to various types of investors. In other words, US subordinated debt is ultimately a certificate held by the Fund and its various investors. During President Bush's term of office, the US government implemented the low-interest rate policy for many years, which led to the unprecedented popularity of speculation. However, once the interest transmission chain breaks, it will eventually become the outbreak of the sub-prime debt crisis.

In 2007, the US sub-prime crisis mainly originated in some aspects [7-8]. Homeowners are unable to repay the mortgage loans (mainly due to the replacement of adjustable-rate mortgages, borrowers' excessive lending, predatory lending, and speculation), excessive construction during the prosperous period, and the risk of mortgage products-the most serious harm of thousands of square meters of housing loan products of financial institutions, leading to a virtual expansion in the financial field., mortgage lending institutions increased power, high levels of personal and corporate debt, spreading and may cover up the risk of mortgage default financial products. By 2008, the total size of us sub-prime assets had exceeded us $\$ 1$ trillion, accounting for more than 7\% of us GDP. According to Nobel laureate economist Paul Krugman, "In early 2007, assetbacked commercial paper conduits, in structured investment vehicles, in auction-rate preferred securities, tender option bonds and variable rate demand notes, had a combined asset size of roughly $\$ 2.2$ trillion. Assets financed overnight in triparty repo grew to $\$ 2.5$ trillion. Assets held in hedge funds grew to roughly $\$ 1.8$ trillion. The combined balance sheets of the then five major investment banks totaled $\$ 4$ trillion. In comparison, the 
total assets of the top five bank holding companies in the United States at that point were just over \$6 trillion, and total assets of the entire banking system were about $\$ 10$ trillion." [9] U.s. citizens are greedy for hope. Lowincome groups in order to have a house, with a far higher than their ability to pay to full desire. In addition, the high-income group not only consumes all of their salaries but also uses credit cards to enter into a large amount of over-spending, which is an important cause of the U.S. economy's over-weakness [10-11]. Household debt increased from US\$ 705 billion at the end of 1974 to US\$ 7.4 trillion at the end of 2000year, and finally increased to US\$ 14.5 trillion in mid-2008, accounting for $134 \%$ of the total amount in disposable personal income. In 2008, a typical American family had 13 credit cards, and $40 \%$ of them had balances, which was higher than $6 \%$ in 1970. [12]In the classical crisis, overproduction manifested itself as insufficient effective demand and unsold goods, which eventually led to financial turmoil. In the contemporary crisis, overproduction is an indirect table that is now effective demand is not enough, direct performance false strong demand, even table is now a false demand "excessive", "overdraft consumption". In July 2007, the U.S. financial sector erupted in a series of large-scale financial institution closings, with the government taking over fannie mae and fannie mae, the rayman brothers and the acquisition of bear stearns and merrill lynch shocking the whole world. At this point, the U.S. financial crisis caused by sub prime crisis spread everywhere.Denice a. Gierach, a real estate lawyer and certified public accountant, wrote that "most of the commercial real estate loans were good loans destroyed by a really bad economy. In other words, the borrowers did not cause the loans to go bad, it was the economy." [13]

With the acceleration of the process of global economic integration, no country in the world can stand on its own, which will be more or less affected. "such as the U.S. meteorologist EdwardLorenz (edward lorenz, 1979), put forward the "butterfly effect." The International Monetary Fund estimated that, " large U.S. and European banks lost more than \$1 trillion on toxic assets and from bad loans from January 2007 to September 2009. These losses were expected to top $\$ 2.8$ trillion from 2007 to 2010. U.S. banks losses were forecast to hit $\$ 1$ trillion and European bank losses will reach \$1.6 trillion. The IMF estimated that U.S. banks were about 60 percent through their losses, but British and Eurozone banks only 40 percent."[14]

\subsection{U.S. Government's Strategy to Deal with Economic Crisis}

The Strategies of Successive US Administrations in Coping with Economic Crises Any set of economic policies are supported by economic theory and mainly have two aspects: one is economic liberalism; the second is state interventionism. In 1857, the U.S. broke out in the period of the economic crisis. The total economic volume of the capitalist countries was not large, and the government's ability to do economic prewar was limited. The scope of economic interaction was relatively narrow. In view of the economic thoughts that were free to let go at that time that wanted to occupy the position of governing the whole country, the U.S. economic crisis in 1857 completed the adjustment and recovery of the economic crisis through the internal self-repairing mechanism of the capitalist countries' economic bodies. Later, the economic crisis that broke out in the United States was far-reaching in both breadth and depth. In response to the economic crisis, successive administrations of the United States adopted corresponding countermeasures and achieved good economic and social results.

The US sub-prime financial crisis, which began in August 2007, is qualitatively different from the previous three economic crises. This crisis is mainly due to the excessive and advanced cost reduction by the US citizens, especially the excessive and innovative cost reduction by the US residents in the housing industry and the financial sector. In this way, the credit of the United States will expand. However, once the subprime mortgage loan can not be repaid in time, the subprime mortgage institution will be forced to declare bankruptcy and the investment funds will be closed, which will lead to serious stock market turmoil and financial institution bankruptcy. In 2008, the U.S. unemployment rate rose to the highest level in 15 years. Businesses began to lay off workers on a large scale. In the third quarter of 2008, U.S. businesses laid off more than 1.2 million workers. The total number of workers laid off was the highest in nearly 30 years. 


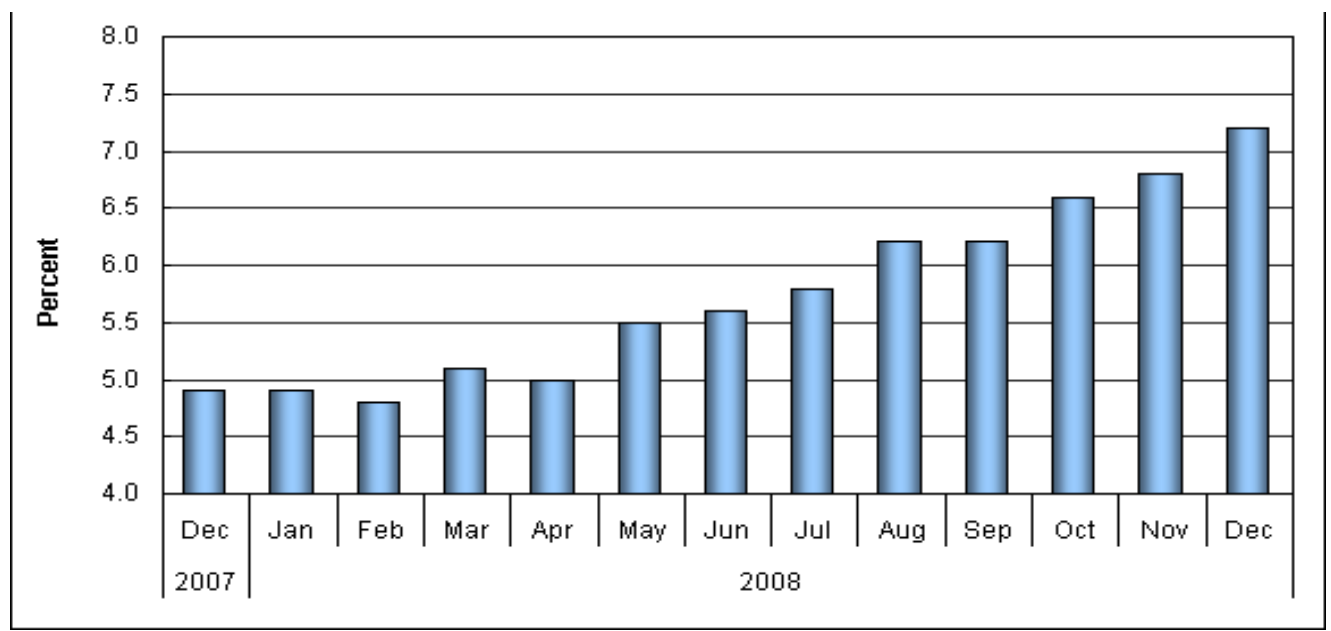

Figure1. The unemployment rete from December 2007- December 2008

The important task of saving the US economy naturally falls to the new President of Obama. In his speech to the national radio and the internet after his arrival on stage, Mr. Obama told the American people about his economic and rescue plan. Obama previously announced the five major contents of the economic recovery plan: government energy conservation, starting the largest infrastructure construction, launching a largescale school hardware upgrading campaign, changing into the medical situation, and the general and broadband network. [15]It will focus on initiating the largest investment in infrastructure since the 1950s, which will greatly boost employment. First, it is necessary to upgrade the school facilities all over the country, install computers and wide belts, and adopt new energy-saving technologies to build "21st-century" schools, so as to strengthen the talent competition of the United States in the international economy. Second, the large-scale renovation of the US-China public buildings. Before, the energy consumption of US-China buildings was very high. After the renovation, the buildings will become very energy-efficient. Measures such as installing energy-saving lamps in the buildings or replacing the old heating system will be taken. These measures will not only create a lot of jobs in the industry but also save energy and source expenses, which is in line with today's environmental protection topics to be noticed. Third, a number of new expressways will be built, which is the largest investment in infrastructure since the US built its expressway network in the 1950s. In addition, they will not include the construction and renovation of old airports, public roads, and bridges, to stimulate economic growth and employment, so that the US economy can slowly emerge from the crisis. Fourth, plans to invest huge funds to popularize broadband services, and improve public online speed. Fifthly, the plan helps to improve and modernize the medical system in the United States, ensuring that every doctor can use advanced medical equipment and avoid medical accidents as much as possible [16]. The cost of the stimulus was estimated at about $\$ 787$ billion when it was passed and was revised to $\$ 831$ billion between 2009 and 2019.In July 2010, the White House Council of Economic Advisers (CEA) estimated that the stimulus had "saved or created between 2.5 and 3.6 million jobs as of the second quarter of 2010" [17].

Compared with the Bush administration's measures to deal with the US financial crisis, the Obama administration's "economic recovery" plan has two remarkable characteristics. The first notable feature is the combination of large-scale infrastructure and enhanced international competitiveness. The second notable feature is the combination of large-scale infrastructure construction and promoting energy conservation, environmental protection and economy. It is hoped that through the establishment of a green economic system, employment can be created through the spillover of related infrastructure. This plan is worth close attention because it can make the us economy out of the crisis. At the same time, it can ensure the healthy and sustainable development of the US economy.

\subsection{The Enlightenment of the American Sub- prime Crisis for China}

First, as long as the deposit in the social production, production capacity will continue to increase, but the consumer demand is growing slowly, when overproduction and effective demand is not enough between the contradiction between deposition to a certain extent, the economic crisis will burst hair, and the dangerous machine always shows the characteristics of the cycle. Therefore, when expanding investment, the government should pay attention to expanding the relationship between energy production and industrial structure adjustment, and avoid redundant construction. At the same time, the government should pay attention to strengthen the reform of the distribution system, so as to ensure that workers' wages and other income keep 
pace with economic growth. Avoiding the emergence of overcapacity and effective demand is not enough between the contradictions.

Second, as China continues to open wider to the outside world, its economic integration into the global economy has deepened. Its outward dependence on economic growth has further increased. The Chinese government should always keep a high warning of economic growth and the changing trend of developed capitalist countries. Once the economic crisis occurs in capitalist countries, the Chinese government should take timely and appropriate measures to avoid excessive volatility in economic growth.

Third, is not the same as the country's economic development level and the environment is not the same. but to deal with the economic crisis machine strategy generally can be summed up in three aspects. Firstly, keep the stability of the financial, maintain national confidence, and avoid excessive financial volatility; Secondly, increase government investment through cairns investment multiplier effect, pull the economic growth, but should pay attention to avoid low water level heavy recovery construction caused by waste; Third, expanding domestic demand, because the most important thing is to increase employment and ensure that workers have a stable source of income. In addition, the government should strengthen the construction of social insurance system to ensure that the low-income groups will not lead to a significant decline in living standards during the crisis.

\section{Conclusion}

From the above analysis, it is not difficult to see that the experience and lessons of the U.S. sub-prime crisis can provide important experience for China to avoid the outbreak of the systemic financial crisis. The sub-prime crisis swept across the world, and China's economy was inevitably affected. Starting from the formation process and causes of the sub-prime crisis in the United States, this paper expounds the influences of the sub-prime crisis on the Chinese economy, and advances some countermeasures for preventing the sub-prime crisis. Only by fully drawing on the experience and lessons of other countries in history can the Chinese government better avoid the outbreak of a systematic financial crisis and maintain the sustainable growth of the Chinese economy.

\section{ACKNOWLEDGMENT}

I would like thank the professor who provides me with abundant guidance and encouragement during the research, and I would also express my gratitude towards all my friends who give their valuable 1 advice on this research.

\section{REFERENCES}

[1] L. Neal, (May-June 1998), "The Financial Crisis of 1825 and the Restructuring of the British Financial System" (PDF), Review, Federal Reserve Bank of St. Louis, 80 (3), DOI:10.20955/r.80.53-76, retrieved June 2012

[2] F. Zakaria, (1999). From Wealth to Power: The Unusual Origins of America's World Role. Princeton UP. p. 46. ISBN 978-1400829187.

[3] J. Fulfer (April 6, 2018). "Panic of 1857: A Story of Speculative Finance". The Economic Historian.

[4] D. Glasner, (1997). Business Cycles and Depressions: An Encyclopedia.

[5] Staff, Investopedia (2003-11-20). "Finance". Investopedia. Retrieved 2018-11-26.

[6] "President Bush's Address to Nation". The New York Times. 2008-09-24. Retrieved 2010-05-24.

[7] S. Michae, Competition and Crisis in Mortgage Securitization

[8] M. J. Dwight, (2010-02-27). The Role of GSEs and Housing Policy in the Financial Crisis

[9] P. Krugman, Wells, Robin (September 30, 2010). "The Slump Goes On: Why?". New York Review of Books. Retrieved 20 November 2013.

[10] Z.1 Historical Tables (1974) and current Z.1 release (2008) Archived 2014-08-11 at the Wayback Machine, Table B.100, lines 31,48

[11] "Zakaria: A More Disciplined America | Newsweek Business | Newsweek.com". Newsweek.com. 2008. Retrieved 2008-10-2

[12] D. Kotz, \& Ding, X. (2004). Journal of Economics of Shanghai School, 2(3), 51-65.

[13] Gierach, A. Denice, "Waiting for the other shoe to drop in commercial real estate", (Chicago, IL, The Business Ledger, March 4, 2010)

[14] "FACTBOX-U.S., European bank writedowns, credit losses". Reuters. 5 November 2009. Retrieved 5 October 2017

[15] Obama details his 'economic rescue plan' http://www.cnn.com/2008/POLITICS/10/13/campa ign.wrap/index.html

[16] "Estimated Impact of the American Recovery and Reinvestment Act on Employment and Economic Output from October 2011 Through December 2011" (PDF). A CBO Report. Congressional Budget Office. February 2012. Retrieved February 19, 2017. 
[17] Council of Economic Advisers, "The Economic Impact of the American Recovery and Reinvestment Act of 2009" Archived August 5, 2010, at the Wayback Machine, July 14, 2010, p. 1. 